\title{
The Disclosure of Shari'ah Non-Compliance Income: Comparative Study between Full-fledged and Subsidiaries Malaysian Islamic Banks
}

\author{
Atharyanshah Puneri* \\ Moustapha Chora Ahmat* \\ Ilhamiddin Ikramovich Nazarov* \\ Hafiz Benraheem*
}

*International Islamic University Malaysia, Jalan Gombak, Kuala Lumpur, Malaysia, 53100

Email:athpun@gmail.com, mouchora@gmail.com, ilhamiddinn@gmail.com, hhbenraheem@gmail.com

\begin{abstract}
The purpose of this paper is to analyse to what extent the Islamic banks in Malaysia practice disclosure regarding Shari'ah non-compliant income. Furthermore, this paper also investigates how the bank distributes the Shari'ah non-compliant income. This paper acquires a qualitative approach. The qualitative approach is adopted by doing a document analysis about the literature from previous studies that discusses the Shari'ah non-compliant income. Based on the data collected, Bank Islam clearly and properly discloses its Shari' ah non-compliance income, and the researchers recommend other Islamic banks to follow it. Also, the study finds out that it does not matter whether they are full-fledged or subsidiaries; the practice is quite the same.
\end{abstract}

Keywords- Islamic Bank, Subsidiary Islamic bank, Disclosure Shari'ah non-compliant income, Malaysia

\section{Abstrak}

Tujuan dari makalah ini adalah untuk menganalisis bagaimana bank-bank Syariah di Malaysia mencatatkan pendapatan non-syariahnya. Lebih jauh lagi, makalah ini juga menelusuri bagaimana bank-bank syariah di Malaysia mendistribusikan pendapatan non-syariahnya. Makalah ini menggunakan pendekatan kualitatif dengan melakukan analisa dokumen yang ada terkait pendapatan non-syariah bagi perbankan Islam. Berdasarkan data yang berhasil didapatkan, Bank Islam merupakan Bank Syariah di Malaysia yang dengan jelas mencatatkan dan melaporkan pengelolaan pendapatan non-syariahnya.

Kata Kunci-Islamic Bank, Subsidiary Islamic bank, Disclosure Shari'ah non-compliant income, Malaysia

\section{INTRODUCTION}

Islamic banks are subject to a unique set of risks, including equity investment risk, displaced commercial risk; and Shari'ah noncompliance risk, which is considered one of the most critical risks. Shari'ah's non-compliance risk illustrates a possible failure to comply with obligations or the principles of Shari'ah in carrying out the finance business activities and operations as set out in relevant jurisdictional standards and broadly accepted international Shari'ah standards (Rosman, Azmi, and Amin, 2017). Compliance with Shari'ah is an exclusive and central element of Islamic finance. Any failure to comply with the Shari'ah law will adversely affect the trustworthiness of Islamic finance and the trust of market participants among depositors and investors. Islamic finance must, therefore, ensure that Shari'ah non-compliance income is audited, disclosed and adequately managed; otherwise, the difference between Islamic and conventional finance will be blurred (Salman, 2018).

The management of Shari'ah noncompliance income is critical; failure to comply with Shari'ah by full-fledged Islamic or subsidiaries may have an impact on a bank's sustainability and reputation. More important disclosures in these areas are essential to the users of financial information, including the 
investment account holders, shareholders, regulators, and the public at large. Moreover, among the importance of substance in Islamic financial institutions is to provide transparency and full disclosure of Shari'ah non-compliance income. As it is known, the Islamic financial system operates by the principles and teachings of Shari'ah law. Malaysia's Islamic banking system is considered more progressive than that of other Muslim countries, that have implemented similar policies (Hasan, 2010). The Malaysian regulatory authority has adopted a proactive approach to promoting a steadily increasing Islamic component in the dual banking system, including conventional and Islamic banking, where both are regulated by the Bank Negara Malaysia (BNM). The Central Bank of Malaysia attaches great importance to ensuring that the Islamic financial system as a whole operates in accordance with the principles of Shari'ah (BNM, 2010). Despite these requirements and regulation, some banks are yet to follow these requirements adequately in disclosing and disbursing their Shari'ah non-compliance income. Nevertheless, the emphasis on Shari'ah risk management is growing slowly. Many are not addressing Shari'ah risk management in its length and breadth, but are pleased with its inclusion in operational risk management (Salman, 2018).

This study intends at first to analyse to what extent the Islamic banks in Malaysia practice disclosure regarding Shari'ah noncompliant income as well as to identify the best practices among Islamic banks by comparing between full-fledged and subsidiaries Malaysian Islamic Banks. Hence, the authors have selected two full-fledged Islamic bank and two subsidiary Islamic banks, which is Bank Islam Malaysia Berhad, Bank Muamalat, OCBC Al-Amin and Public Islamic Bank starting from 2015 until 2017.

\section{LITERATURE REVIEW}

\section{Background of Islamic Bank}

Modern Islamic finance exists since the seventies of the last century. Before expanding to western countries, it was traditionally based in the Middle East and Asia. Importance of Islamic finance grew due to the growing awareness and demand for Shari'ah-compliance products among Muslims. Even in western countries, the interest has been increasing toward Islamic finance and Shari'ah-compliance products due to multiple reasons such as the facilitation of investments and trade with Muslim countries and the attraction of new sources of capital. After the global economic crisis, the interest in Islamic banking proliferated as one of the essential segments of Islamic Financial Industry. Many expect that Islamic finance would provide a solution for the global economic crisis if its mechanism implemented accurately. Historically, it was proved that reckless lending practices and greedy exploitation had caused a crisis. Islamic banking may satisfy the human needs and fulfil the essential objectives of the Shari'ah by preserving and increasing wealth according to the teachings of Islam (Ibrahim, Elatrash, \& Farooq, 2014).

\section{Definition and the role of Islamic Banks}

The scope of Islamic banking activities includes all currently known in the banking system, excluding borrowing and lending based on interest or involved in activities which have a high level of risk and gambling. Al Manaseer defines Islamic bank as a company whose primary business is to mobilize funds from savers and supply these funds to the entrepreneurs (Al Manaseer, 2007).

Islamic banks can play the role of an investment manager for the owners of the time deposits, usually called investment deposits, as well as commodity and asset trading that constitute an integral part of Islamic banking operations (Al-Jarhi, Ali and Iqbal, 2001).

\section{Shari'ah and the sources}

Islamic banks operate following Shari'ah law and are guided by Islamic economic principles (Fatai, 2012). The Shari'ah is known as an Islamic legal system, Islamic Law or tradition. It is a code of conduct including legal, moral, spiritual, ethical as well as social aspects of the public and private life of a Muslim. The Shari'ah acknowledges contractual freedom unless the contract or certain provisions of a contract are prohibited by the Quran or Sunnah or Ijma (Tjittes, 2008). 


\section{Financing Modes:}

The Shari'ah prohibits usury/Riba, risk/ Gharar, gambling/Maysir and investments in non-Shari'ah-compliance activities such as alcohol, drugs, pork, pornography, gambling and arms, etc. The Islamic banks may direct idle savings to various channels of Islamic investment packages, such as Murabahah (Cost plus), Mudharabah (Profit-sharing), Musharaka (Joint venture), Musharakah Mutanaqisah (MM - Diminishing Partnership), Bai' Bithaman Ajil, Ijarah (BBA - Deferred Payment Sale), Ijarah (Leasing), Istisna' (Contract Manufacturing), etc. In general, Islamic banks play an important in the comprehensive development process by attracting funds for various financial activities.

\section{Islamic Banking in Malaysia}

Malaysia is one of the first countries that started with Islamic Finance. The country is one of the frontrunners that tries to develop new instruments that are required to comply with Islamic law. Moreover, Malaysia has been promoting an Islamic Interbank money market to connect all the players on the Islamic Financial market and to improve shortterm liquidity (Yasin, 2007). Islamic finance continues growing rapidly, reinforced with an encouraging environment that is well-known for constant product innovation, providing a comprehensive financial infrastructure, adopting global regulatory and legal best practices. The country has also placed a strong emphasis on human capital development to ensure the availability of Islamic finance talent. All of these value propositions have transformed Malaysia into one of the most developed Islamic banking markets in the world (Khiyar, 2012).

The dual-banking system, for the first time, was implemented where the Islamic banks operate side-by-side with the conventional one (Yusoff, 2004). The dual financial system has proven to be viable, more competitive and sophisticated Islamic financial products have been introduced into the Islamic banking industry, gained popularity and preferred by the customers (Muda and Jalil, 2007). Many Islamic countries have recognized the Malaysian model as the model of the future, and many countries have shown interest in adopting this system (Mokhtar et al., 2006). The first establishment of Islamic institution can be traced back to 1963 when the government commenced Tabung Haji (the Pilgrims Management and Fund Board). To invest the savings of the local Muslims in interest-free places, who plans to save for Hajj. Furthermore, the first call for a separate Islamic bank was made in 1980, in a seminar held at the National University of Malaysia. The participants requested from the government to pass a special law for initiating an Islamic bank in the country. The government had found a committee in 1981 to study legal, religious and operational aspects of the scheme.

In 7th April 1983, the Islamic Banking Act was introduced. This Act summarized the rules and guideline which Islamic banks must conform to operate in Malaysia. Bank Negara Malaysia (BNM) was empowered to supervise and regulate Islamic banks within the country (Haron and Azmi, 2008). In the $1^{\text {st }}$ of July 1983, Bank Islam Malaysia Berhad (BIMB) started operating. Later, the conventional banking institutions were allowed to offer Islamic banking products and services using their existing infrastructure, including their staff and branches. In October 1996, BNM issued a model of financial statement for the IFIs requiring them to disclose their Islamic banking operations to strengthen the development of the Islamic banking system in Malaysia. On 1st October 1999, Bank Muamalat Malaysia Berhad as a second full-fledged Islamic bank was licensed by BNM. In 2004, BNM approved the applications of three new full-fledged foreign Islamic banks to operate in Malaysia, namely Kuwait Finance House, Al-Rajhi Banking and Investment Corporation and the consortium led by Qatar Islamic Bank (Mokhtar et al., 2006). Despite the challenging economic environment, the continued expansion of Islamic finance has demonstrated its viability and resilience.

The Islamic Financial Services Act 2013 was enacted to provide regulation and supervision for Islamic financial institutions, payment systems and other relevant entities and the oversight of the Islamic money market and Islamic foreign exchange market (IFSA, 2013). 


\section{Shari'ah Governance Framework}

As known, Islamic banking is that, the conduct of banking in accordance with the principles of Shari'ah law. Shari'ah is mostly defined as Islamic law, however for a best and more suitable definition of Shari'ah, according to a code of law or divine injunctions that regulate the conduct of human beings in their individual and collective lives" (Ayub, 2007). Meanwhile, Ayub defined Shari'ah as "Shari'ah refers to a code of law or divine injunctions that regulate the conduct of human beings in their individual and collective lives". Hence, it can be gathered from the Shari'ah governance framework (SGF) which is a set of organizational arrangements through which Islamic financial institutions ensure effective oversight, responsibility and accountability of the board of directors, management and Shari'ah committee. The framework serves as a guide towards providing an operating environment that is compliant with Shari'ah principles at all times (IFSB-10, 2009).

\section{Function of Shari'ah governance}

Shari'ah governance aims to ensure Shari'ah compliance in the real practice either in Shari'ah legitimacy of products or Shari'ah-compliant operation of Islamic financial institution. Shari'ah governance serves to enhance the confidence and trust of stakeholders with respects to the perception of the outsiders and also the public confidence (BNM, 2010). Shari'ah Compliance aspects are to be observed throughout the process in developing or constructing the products or framework and to be supported by proper Shari'ah governance functions.

\section{Shari'ah Governance Structures for IFI in Malaysia}

Bank Negara Malaysia (BNM) has established the necessary mechanism for the Islamic financial system to operate in a manner consistent with Shari'ah Muamalah principles, with a clearly defined institutional arrangement within Islamic financial institutions regulated by BNM. A two-tiered Shari'ah governance structure has been established, comprising an apex Shari'ah advisory body at BNM and a supervisory Shari'ah committee formed at the respective Islamic financial institutions (BNM, 2010).

\section{Shari'ah Advisory Council:}

The Sariah advisory council of Bank Negara Malaysia (SAC) was established in 1997 as the highest authority to set on all Shari'ah matters that related to Islamic Banking and Takaful industry. It serves as the final arbiter in the interpretation of Shari'ah principles on Islamic Banking and Takaful matters and practices. It promotes the harmonization of Shari'ah interpretations among the Shari'ah committees residing in the individual Islamic financial institutions. The Function of SAC as provided under section 52 of the Central Bank Malaysia Act (CBMA) 2009 as follows:

To ascertain the Islamic law on any financial matter and issue a ruling upon a reference made to it by this Part, to advise the Bank on any Shari'ah issue relating to Islamic commercial business, the activities or transactions of the Bank, to provide advice to any Islamic financial institution or any other person as may be provided under any written law, and such other functions as may be determined by the Bank (BNM, 2009).

\section{Shari'ah Committee:}

The Islamic Financial Services Act 2013 (IFSA) came into force on June 30, 2013. The new act repeals the earlier legislations: Islamic Banking Act 1983, the Takaful Act 1983, Payment System Act 2003 and Exchange Control Act 1953. The Guidelines on the Governance of Shari'ah Committee for the Islamic Financial Institutions was issued to determine the role, duties, and responsibilities of Shari'ah committee and its members and the relationship and working arrangement between the Shari'ah committee at individual institutions and the SAC at the national level.

For the establishment of the Shari'ah committee, section 30 of Shari'ah governance of IFSA 2013 list that:

A licensed person shall establish a Shari'ah committee for purposes of advising the licensed person in ensuring its business, affairs and activities comply with Shari'ah.

For the objective of subsection one, if there is more than licensed person inside a financial 
group, one of the authorized individuals may apply to Bank Negara Malaysia (the bank) for the foundation of a single Shari'ah committee inside the business group. Also, the Bank may accept the application in writing if the Bank has contended that the SC so settled is fit for ensuring compliance with Shari'ah by all authorized individuals inside the financial group.

The Bank may require an affirmed individual or operator of an assigned payment system to set up a Shari'ah Committee for reason of advising the confirmed individual or operator of a designated payment system in ensuring their business, activities, and affairs comply with Shari'ah.

The principal objective of the new Islamic Financial Services Act 2013 is to ensure Shari'ah compliance:

1- an institution shall all the time ensure that its aims and operation, business, affairs and activities comply with Shari'ah.

2-for the purpose of this Act, compliance with any ruling of the Shari'ah advisory council in respect of any particular aim and operation, business, affairs or activities shall be deemed to be compliance with Shari'ah in respect of that aims and operation business, matters or activities.

About the duties of Shari'ah Committee, section 32 of IFSA 2013 indicate that a Shari'ah committee and each individual from the Shari'ah Committee will have such obligations and capacities set out in any benchmarks as might be indicated by the Bank under subparagraph 29 (2) (a) (i). Furthermore, section 35 talks about the information should provide to Shari'ah committee: first, an institution and any chief, officer or controller of such foundation will: Give any document or data within its or his knowledge, or fit for being obtained by it or him, which the Shari'ah Committee may require; and make sure that such document or information gave under paragraph (a) is exact, finished, not false or deceiving in any material particular.

second, With the exception of as given in section 36, a member of a Shari'ah committee should not reveal any document or information outfitted under subsection (1) to some other individual (IFSA, 2013).

\section{Shari'ah Non-Compliance Risk in Islamic Banks}

Risk can be defined in many terms. One of them is that risk can be defined as the combination of the likelihood of a hazardous event occurring with the possible accompanying loss or unwanted consequences (Hubbard, 2007).

Risk also being recognized in the banking world. Both of Islamic and Conventional Banks are exposed to some risk. But, because of the difference in form and substance of banking activities between Islamic Banks and Conventional banks, it caused some differences in risk profile for Islamic Banking. The disagreements of risk profile between Islamic Banks and Conventional Banks are shown in the table below:

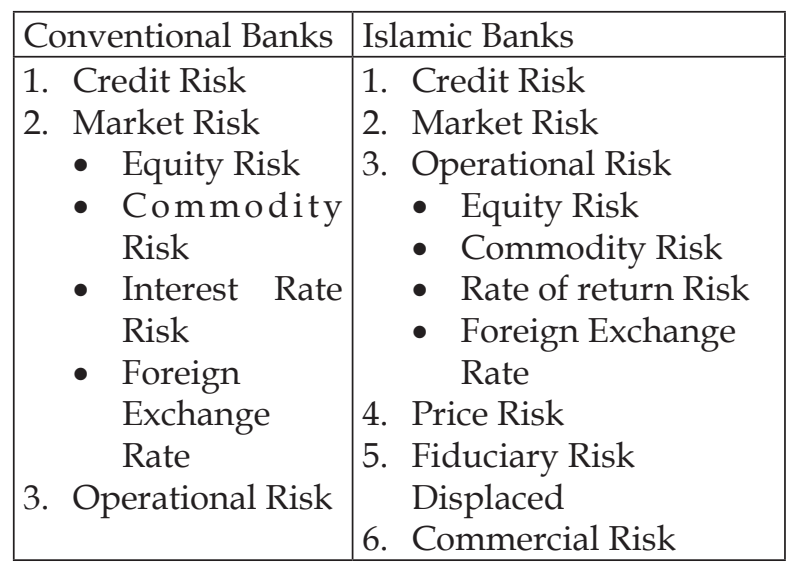

Source: (Reyazat, 2012)

As for Islamic Banks, they also have unique risks, which are (Reyazat, 2012):

Shari'ah non-compliance risk: Risk that arises from the failure to comply with Shari'ah rules and principles

Rate of Return Risk: The potential risk that can arise on the return caused by an unexpected change in the rate of returns.

Displaced Commercial Risk: The risk that the bank may confront commercial pressure to pay returns that exceed the rate that has been earned on its assets financed by the investment account holder.

Equity Investment Risk: The risk that arises from entering into a partnership to undertake or participate in a special financing or general business activity as described in the contract. This risk is relevant to Mudharabah and Musharakah contract. 
According to the study that is conducted by Rosman, Azmi, and Amin (2017), out of four those unique risks that are mentioned above, Shari'ah non-compliance risk is the most critical one. Because it highlights possible failure to meet the obligations or satisfy the Shari'ah principle as prescribed in the relevant jurisdiction's set of standards and widely accepted international set of Shari'ah standards, and managing this risk is very important for Islamic Banks. This is because if there is an Islamic Bank failed to comply with the Shari'ah standards, then it will have an impact on that Islamic Bank's sustainability and also reputation.

IFSB, on IFSB-1, defines Shari'ah noncompliance risk as to the risk that arises because of Islamic Bank's failure to comply with the Shari'ah rules and principles which are determined by the Shari'ah board or relevant body in the jurisdiction in which the Islamic Bank operates (IFSB, 2005). Shari'ah compliance is a consistent process which should be maintained at all times, and such compliance requirements must absorb throughout all of the Islamic Banks' organization, products and activities. On both funds seeking side as well as the financing sides, Islamic Banks must ensure that their operations and products must comply with all of Shari'ah requirements.

Shari'ah non-compliance risk in Islamic Banks might arise and identify through the underlying Shari'ah contracts applied. Although Shari'ah non-compliance events may occur on various occasions and various forms, below will be mentioned non-Shari'ah risk profile that might arise for each particular Shari'ah contract applied.

\section{Murabahah Contract:}

AAOIFI defines some of Shari'ah noncompliance risk that potentially arise in this type of contract are (AAOIFI, 2010):

- The parties to the contract are ineligible to execute it.

- The asset is sold to a customer before the bank purchases it from the developer.

- The original price or markup has not been disclosed to the customer.

- The disclosed price and/or markup does not reflect the actual cost price and/or markup.

\section{Tawarruq Contract:}

Ghazali found that some of the Shari'ah noncompliance risks that might arise from this type of contract are (Ghazali, 2014):

- The Tawarruq arrangement is used to grant financing facilities to an individual or nonindividual entity whose activities explicitly involve Shari'ah non-compliant elements, such as ribu-based transactions, liquor production, gambling and brothels.

- While using the bank's name, the bank's staff are engaged in Shari'ah non- compliant activities with clients.

- The commodity and/or collateral used for the Tawarruq arrangement is Shari'ah noncompliant.

- The contract is executed before the bank possesses the commodity.

- The series of sale transactions do not follow the sequential process appropriately.

\section{Istisnā Contract}

Bank Negara Malaysia defines some of the Shari'ah non-compliance risks that might arise from this type of contract are:

- The parties entered are ineligible to execute the contract.

- The asset is not properly specified in the agreement.

- The istisnā asset to be constructed and/or its purpose is not Shari'ah compliant.

- The istisnā asset is already available or completed at the time of execution of the istisnā' contract.

- The parties have failed to determine or agree on the price at the time of execution of the istisna $\bar{a}^{-}$contract.

- The manufacturer unilaterally increases the price of the istisna $\bar{a}^{\prime}$ asset as a result of a request for extension of the payment period.

\section{Ijarah Contract}

Oz, Khokher, Ali, \& Rosman found that some of the Shari'ah non-compliance risks that might arise from this type of contract are:

- The parties to the ijärah contract are ineligible to enter into the contract.

- The ijärah asset and/or its purpose is not Shari'ah-compliant.

- One asset is used for multiple lease contracts simultaneously. 
- The lessor stipulates the conditions for waiving his liability for any defect in the ijārah asset.

- The lessee breaches the conditions agreed by both parties for utilization of the ijärah asset.

- The lessor imposes a condition on the lessee to be held liable for any loss or defects in the ijärah asset.

\section{Mudharabah Contract}

AAOIFI defines some of the Shari'ah noncompliance risks that might arise from this type of contract are:

- The mudârib does not adhere to the terms and conditions stipulated by the capital provider (Rabb al-māl).

- The mudadrib does not act in the interest of the capital provider.

- The capital provider stipulates a condition to guarantee the capital and/or profit.

- The capital value is not determined and agreed at the time of execution of the contract.

\section{Musharakah Contract}

AAOIFI defines some of the Shari'ah noncompliance risks that might arise from this type of contract are:

- The contract clause stipulates that the managing partner or certain partners are required to guarantee the capital against any financial loss.

- The amount of capital to be contributed by each partner is not specified and determined at the time of execution of the contract.

- The contract clause stipulates a predetermined fixed amount of profit to the partners.

- Certain partners are required to undertake the purchase of other partners' shares at par/nominal value.

\section{Disclosure of Shari'ah Non-Compliance Income}

In Islamic banking systems, financial information is essential to the shareholder or depositors in making their investment decisions. Shari'ah non-compliant income which is a proxy for Shari'ah non-compliant risk (Basiruddin and Ahmed, 2017). The central bank of Malaysia gives a direction about how to disclose the Shari'ah non-compliant income:
Income derived from Shari'ah non-compliant activities which may alternatively be disclosed under the Director's Report or Shari'ah Committee's Report. A licensed person shall disclose additional information regarding

(i) nature of Shari'ah non-compliant activities;

(ii) amount of Shari'ah non-compliant income;

(iii)number of non-Shari'ah-compliant events occurring during the year; and

(iv) rectification process and control measures to avoid recurrence of such Shari'ah non-compliant activities.

Bank's financial disclosures should avoid the informational asymmetry problem between the bank's managers and investors (Ibrahim, Ismail and Zabaria, 2011). Despite the guideline given above, the disclosures of Shari'ah noncompliant income in some report do not include any "detailed information" about Shari'ah noncompliant income and its sources $(\mathrm{Oz}$, Khokher and Rosman 2016). Furthermore, the level of Shari'ah non-compliant income is negligible in most cases. Even though, the study from $\mathrm{Oz}$ in 2016 shown that the scenario analysis also demonstrated that even without taking into account the disclosed Shari'ah non-compliant income, the impact of severe stress scenarios on the car is somewhat limited. Also, from another study that is conducted by Rosman, Azmi and Amin are found out that the level of Shari'ah noncompliant income may vary from jurisdiction to jurisdiction because of the effectiveness of the Shari'ah governance framework, including Shari'ah review and audit.

The descriptive analysis from that same study found that Islamic banks in Malaysia and Bahrain are willing to disclose the amount of Shari'ah non-compliant income. Still, they do not want to disclose the nature of this Shari'ah non-compliant income. The majority of Islamic banks in both countries only provide general statements about Shari'ah non-compliant income; they also prefer not to disclose the reasons for having Shari'ah non-compliant income. It is also concerned that stakeholders may require more transparent disclosures of amounts along with the specific nature of the Shari'ah non-compliant income.

Their study also has shown that those Islamic banks that disclose the nature of 
Shari'ah non-compliant income, where most of the Shari'ah non-compliant income result from charging penalties for late payments on Islamic financing facilities.

\section{METHODOLOGY}

The study comprises between Fullfledged and subsidiaries Malaysia Islamic Banks, which is Bank Islam Malaysia Berhad, Public Bank, OCBC Al-Amin, and Public Bank. Annual reports were extracted for the threeyear periods, from 2015 to 2017. A disclosure index is a reliable method for Shari'ah noncompliance disclosure

We also read the entire Shari'ah committee report for each bank. This study is exploratory and using a qualitative method of research. After the data collected, we do the comparative study between the banks, regarding the disclosure of Shari'ah non-compliance income.

Moreover, reviews and analyses the previous literature and other secondary data are being done to conduct the study. The secondary data for this research were also gathered through library research.

\section{FINDING AND DISCUSSIONS}

Bank Islam Malaysia Berhad and Bank Muamalat

SHARI'AH COMMITTEE'S REPORT - 2015

The Bank Islam states the sconces of non-Shari'ah compliance income and clearly explains the channel to distribute those funds.
First of all, the bank, in 2015, has stated in its financial report that four incidences as followed breached the Shari'ah principle:

- Term Deposit Tawarruq-i (TDT-i) Special Overnight (withdrawal of placement before trading)

- Incomplete Tawarruq transaction performed by BICC Telemarketing Sales Agent

- Absence of Tawarruq transaction in Bank Islam Card Renewal

- Inaccurate calculation of Safekeeping Fees for Ar-Rahnu Legacy Accounts

Inside the 2015 financial report, the Bank revealed that RM7,768.02 of Shari'ah noncompliant income which involved commissions from Shari'ah non-compliant merchants of card business, interest received from the Bank's NOSTRO account, and in addition rental purification from the Bank's asset that is used to facilitate bai al-'inah based exchanges.

The table below shows how did the bank disclose the channel of contributing to nonShari'ah income in 2015:

\section{SHARI'AH COMMITTEE'S REPORT - 2016}

Next, throughout 2016, the bank has confirmed two (2) events of Shari'ah noncompliance as follows:

- Incomplete Tawarruq transaction performed through telemarketing sales agent; and

- Remittance services executed for Shari'ah non-compliant purpose.

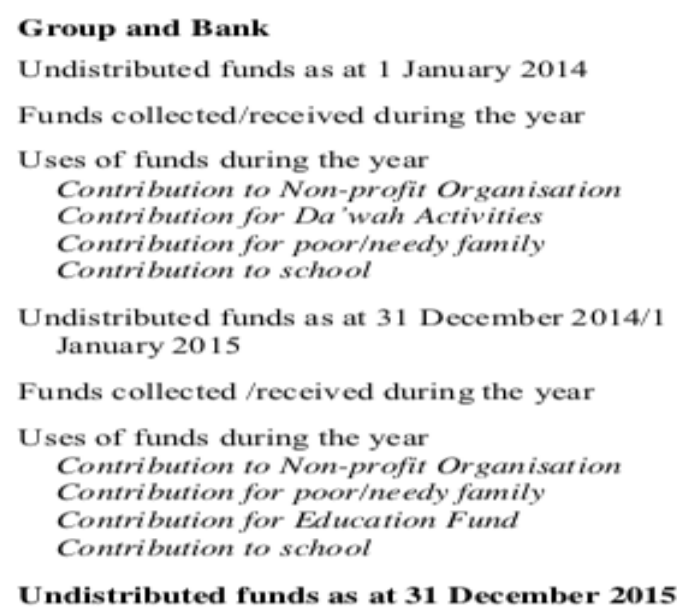

Undistributed funds as at 31 December 2015

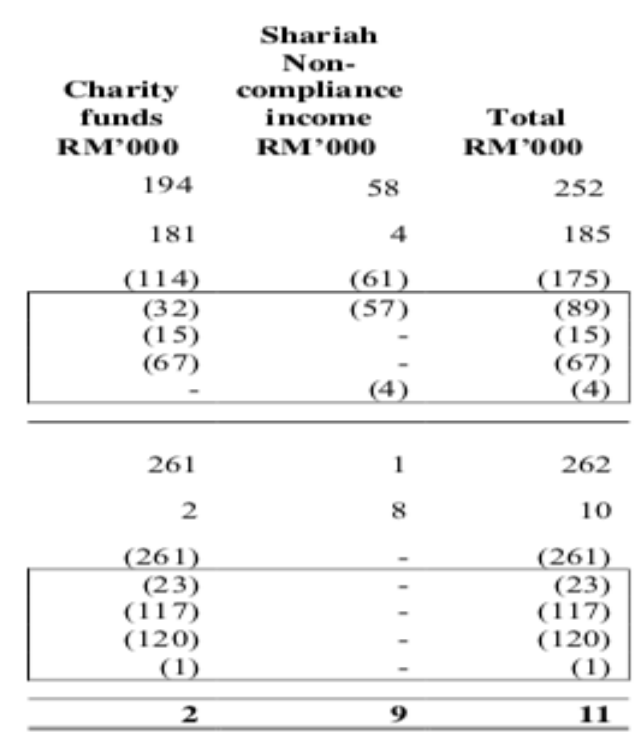


Within the financial year, the Bank detected Shari'ah non-compliant income amounting to RM8,828.95 which includes commissions from Shari'ah non-compliant merchants of card business, interest received from the Bank's NOSTRO accounts and rental purification from the Bank's land that is being used to facilitate bai al-'inah transactions.

The following table shows how does the bank disclose the usage of non-Shari'ah income in 2016:

\section{SHARI'AH COMMITTEE'S REPORT - 2017}

Finally, during 2017, the bank has affirmed three (3) events of Shari'ah non-compliance as follows:

- Four (4) occurrences of the absence of Wakalah contract execution for Term Deposit Tawarruq-i ("TDT-i") in branches;

- $\quad$ One (1) occurrence of absence of wakalah contract execution for Wafiyah Investment Account in branches;

- Overcharge of $t a^{\prime} w i d h$ and profit on Bank Islam Card Credit's customer; and (iv) Absence of commodity trading for TDT-I.

\author{
Group and Bank \\ Undistributed funds as at 1 January 2015 \\ Funds collected/received during the year \\ Uses of funds during the year \\ Contribution to Non-profit Organisation \\ Contribution for poor/needy family \\ Contribution for Education Fund \\ Contribution to school \\ Undistributed funds as at 31 December 2015/1 \\ January 2016 \\ Funds collected/received during the year \\ Uses of funds during the year \\ Contribution to Non-profit Organisation \\ Contribution for Da'wah activities \\ Contribution for poor/needy family \\ Contribution to school
}

Undistributed funds as at 31 December 2016
Inside the financial year, the Bank disclosed Shari'ah non-compliance income accounting to RM8,374.23. This amount was disposed of to charitable causes upon approval of the bank.

The following table shows how does the bank disclose the usage of non-Shari'ah income in 2017:

\section{Comparison}

As mentioned above, it can be seen that Bank Islam clearly and fully discloses its Shari'ah non-compliance income. The bank endeavors to disclose where they received the Shari'ah noncompliance income, how much of the amount of Shari'ah non-compliance income that they received and also, where the bank channelling that Shari'ah non-compliance income.

In contrast with Bank Muamalat, after thoroughly checking its financial report, we found that it has done oppositely. The bank has not disclosed any detail of Shari'ah non-compliance income in any years of its financial statements. Bank Muamalat has only mentioned in the reports that "all earnings that

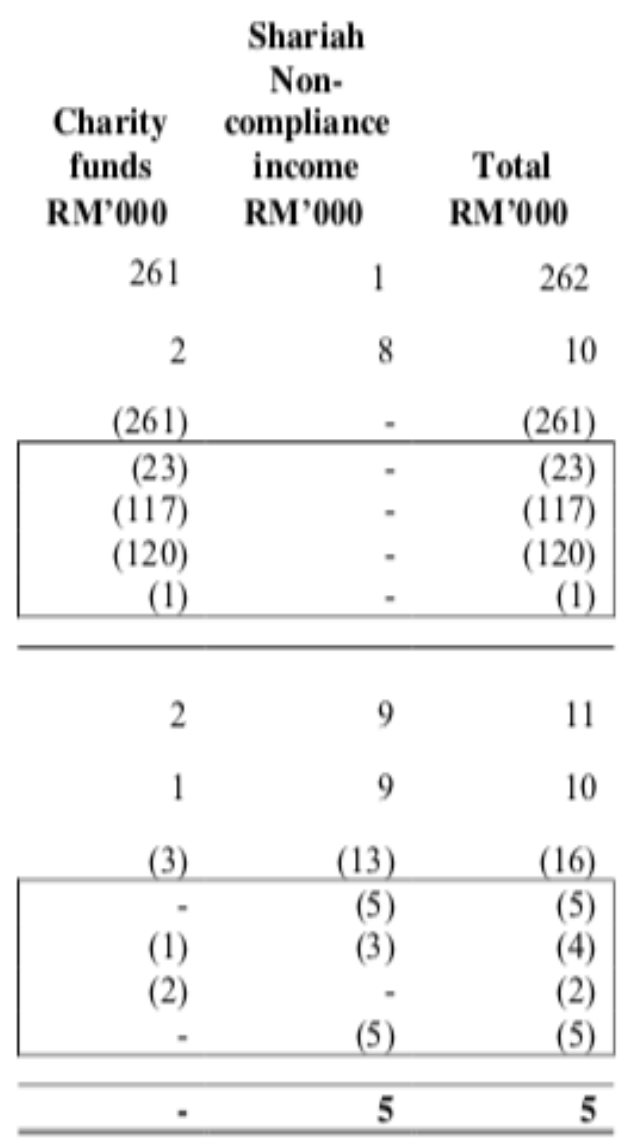




\author{
Group and Bank \\ Undistributed funds as at 1 January 2016 \\ Funds collected/received during the year \\ Uses of funds during the year \\ Contribution to Non-profit Organisation \\ Contribution for $\mathrm{Da}$ 'wah activities \\ Contribution for poor/needy family \\ Contribution to school \\ Undistributed funds as at 31 December 2016/1 \\ January 2017 \\ Funds collected /received during the year \\ Uses of funds during the year \\ Contribution to Non-profit Organisation \\ Contribution for $\mathrm{Da}$ 'wah activities \\ Contribution to Institution
}

Undistributed funds as at 31 December 2017

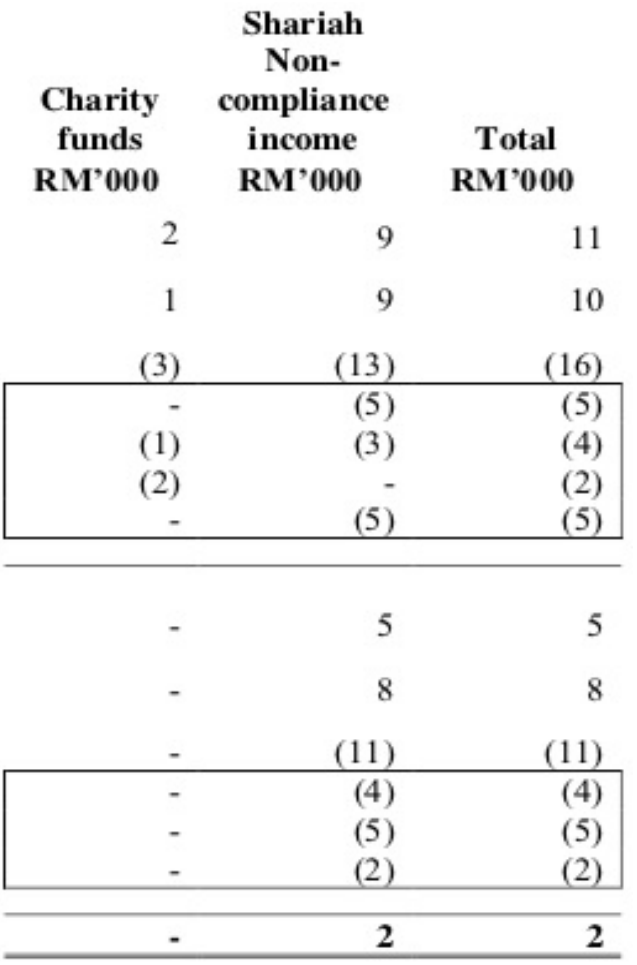

SHARI'AH COMMITTEE'S REPORT - 2016

According to the Shari'ah committee's prohibited by the Shari'ah principles have been identified and excluded from the Bank's income and were disposed of the charitable causes".

OCBC Al-Amin and Public Islamic Bank Berhad

SHARI'AH COMMITTEE'S REPORT - 2015

According to the Shari'ah committee's report; OCBC Al-Amin Bank Berhad during the financial year 2015, the bank received RM2,631 as a Shari'ah non-compliant income from the conventional insurers as a commission. There were three occurrences of Shari'ah noncompliant events identified for the year 2015. The Shari'ah non-compliant activities were due to non-adherence to procedures/guidelines and improper execution of contracts according to the Shari'ah requirements. The distribution of the Shari'ah non-compliant income, it is disclosed under note 34 below.

Actual and Potential Shari'ah NonCompliance Events ("SNCEs") were reported to BNM within the required timeframe set by BNM. The Shari'ah non-compliant income was channeled to charitable organizations as determined by the Bank's Shari'ah Committee. Details of the revenue are as follows: report, OCBC Al-Amin Bank Berhad during the financial year 2016, the bank received RM1,700 as a Shari'ah non-compliant income as a commission from conventional insurers. There were three occurrences of Shari'ah noncompliant events identified for the year 2016. The Shari'ah non-compliant activities were due to non-adherence to procedures, guidelines and improper execution of contracts according to the Shari'ah requirements. The distribution of the Shari'ah non-compliant income, it is disclosed under note 37 below.

Actual and Potential Shari'ah NonCompliance Events ("SNCEs") were reported to BNM within the required timeframe set by BNM. The Shari'ah non-compliant income was channeled to charitable organizations as determined by the Bank's Shari'ah Committee. Details of the revenue are as follows:

\section{SHARI'AH COMMITTEE'S REPORT - 2017}

According to the Shari'ah committee's report, OCBC Al-Amin Bank Berhad during the financial year 2017, the bank did not receive any Shari'ah non-compliant incomes. There were three occurrences of Shari'ah non-compliant 
Sources and Uses of charity funds

At 1 January

Sources of charity funds

Shariah non-compliant income

Uses of charity funds

Contribution to non-profit organisations

At 31 December

\section{Sources and Uses of charity funds}

At 1 January

\section{Sources of charity funds}

Shariah non-compliant income

Uses of charity funds

Contribution to non-profit organisations

At 31 December

\section{Sources and Uses of charity funds} At 1 January

\section{Sources of charity funds}

Shariah non-compliant income

\section{Uses of charity funds}

Contribution to non-profit organisations At 31 December

events which had an immaterial financial loss. The Shari'ah non-compliant events were due to non-adherence to procedures/guidelines and improper execution of contracts according to the Shari'ah requirements. The distribution of the Shari'ah non-compliant income, it is disclosed under note 37 below.

All Potential and Actual Shari'ah Non-Compliance Events ("SNCEs") upon confirmation by Shari'ah Committee were reported to $\mathrm{BNM}$ within the required timeframe set by BNM. Shari'ah non-compliant income is channeled to charitable organizations as determined by the Bank's Shari'ah Committee. Details of the income and uses of charity funds are as follows:
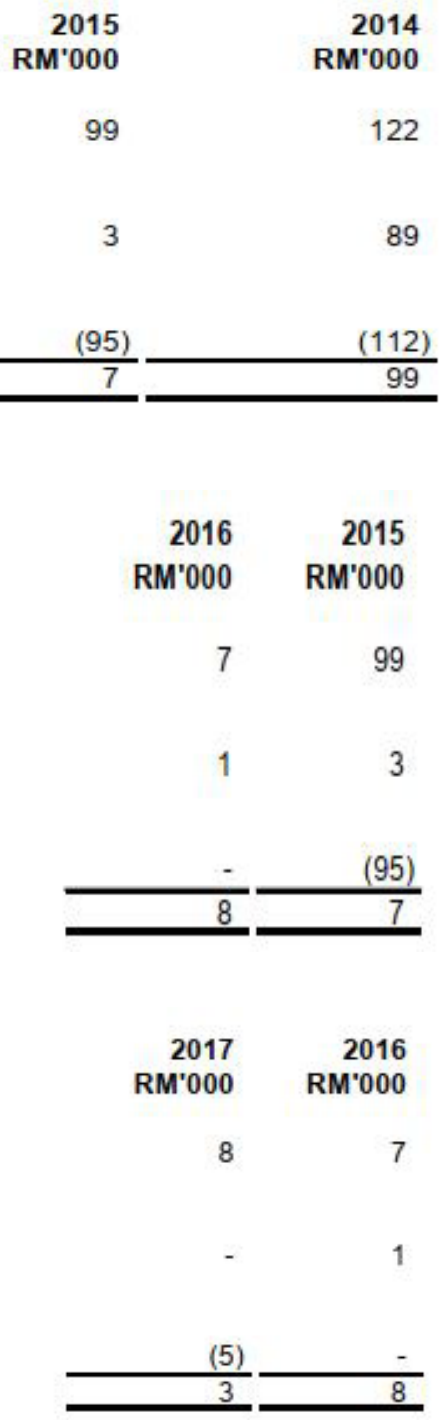

\section{PUBLIC ISLAMIC BANK BERHAD}

SHARI'AH COMMITTEE'S REPORT - 2015

According to the Shari'ah committee's report, Public Islamic Bank Berhad during the financial year 2015, the bank received RM7,000 as a Shari'ah non-compliant income from Gharamah. Shari'ah non-compliant incomes have been considered for disposal to a charitable organization.

\section{SHARI'AH COMMITTEE'S REPORT - 2016}

According to the Shari'ah committee's report, Public Islamic Bank Berhad during the financial year 2016, the bank received RM33,000 as a Shari'ah non-compliant income from Gharamah. Shari'ah non-compliant revenues have been considered for disposal to a charitable organization. 


\section{SHARI'AH COMMITTEE'S REPORT - 2017}

According to the Shari'ah committee's report, Public Islamic Bank Berhad during the financial year 2017, the bank received RM34,000 as a Shari'ah non-compliant income from Gharamah. Shari'ah non-compliant incomes have been considered for disposal to a charitable organization.

There is a mismatch between what the bank stated in the Shari'ah committee report and what the bank stated in the notes. Because in the notes it was revealed that there is no Shari'ah non-compliant income received throughout 2015-2017 financial year.

\section{Comparison}

- Both banks accurately disclosed the source and amount of Shari'ah non-compliant incomes, while the name of the charitable organization was not mentioned.

- OCBC Al-Amin Bank Berhad declared that Shari'ah Non-Compliance Events were reported to BNM, while Public Islamic Bank Berhad did not tackle this point.

- What OCBC Al-Amin Bank Berhad stated in Shari'ah committee's report matches with what they stated in the notes, while there is mismatches in Public Islamic Bank Berhad Shari'ah committee's report and their notes.

- Based on this study, we found that OCBC Al-Amin Bank Berhad discloses their Shari'ah non-compliant incomes more appropriately rather than Public Islamic Bank Berhad.

- OCBC shows that they can manage their Shari'ah non-compliance risk better than the Public Islamic Bank because Shari'ah non-compliance income reduce yearly, and by the end of 2017 financial year it was nil.

\section{CONCLUSIONS AND RECOMMENDATION}

To fulfil with the first objective, the authors found that most Islamic banks in Malaysia, whether it's full fledge or subsidiaries, they have enough disclosure for reporting their Shari'ah non-compliant income. Based on the findings of this study, Bank Islam clearly and accurately discloses its Shari'ah noncompliance income, and we recommend any other Islamic banks to follow it. Even though the level of disclosure is slightly lower, but two subsidiaries are commendable in term of the afford of the disclosure.

Another conclusion that can be found in this study is it does not matter whether they are full-fledged or subsidiaries; the practice is quite the same. Note that in terms of managing Shari'ah non-compliance risk, OCBC is better because Shari'ah non-compliance income reduce yearly, and by the end of 2017 financial year it was nil. Lastly, all of the Islamic banks should enhance their level of transparency in any detail. Thus, not only the users of the information but all parties can benefit from the disclosure.

\section{REFERENCES}

AAOIFI. (2010). Shari'ah Standards for Islamic Financial Institutions. Bahrain: AAOIFI.

Ahmad Salman, S. (2018). Shari'ah NonCompliance Risk Management in Takaful Industry. 10.

Al Manaseer, M. (2007), “The Determinants of Islamic and Traditional Bank Profitability: Evidence from the Middle East", PhD Thesis, the University of the West of England.

Ayub, M. (2007). Understanding Islamic Finance. Proceedings of the Academy of Natural

Bank Negara Malaysia. (2014). Istisna Concept Paper. Kuala Lumpur: BNM.

Basiruddin, R., \& Ahmed, H. (2017). “The Role of Corporate Governance on Shari'ah NonCompliant Risk: Evidence from Southeast". Paper presented at KFUPM Islamic Banking and Finance Research Conference, Dhahran November 2017.

BNM. (2009). Prudential Regulation and Supervisory Framework Introduction, 99.

BNM. (2010). Shariah Governance Framework for Islamic Financial Institutions. Federation of Malaysia, Edict of Government: Bank Negara Malaysia.

Fatai, B. O. (2012). Can Islamic Banking Work in Nigeria? Journal of Sustainable Development in Africa, 14(2), 25-40.

Ghazali, N. b. (2014). Tawarruq in Malaysian Financing System: A Case Study on Commodity Murabahah Product at Maybank Islamic Berhad. Kuala Lumpur: University of Malaya.

Haron, S. and Nursofiza Wan Azmi, W. (2008), "Determinants of Islamic and 
conventional deposits in the Malaysian banking system", Managerial Finance, Vol. 34 No. 9, pp. 618-643.

Hasan, Z. (2010). Regulatory framework of Shari'ah governance system in Malaysia, GCC countries and the UK. Kyoto Bulletin of Islamic Area Studies, 3-2(March), 82115.

Hubbard, D. W. (2007). How to Measure Anything, Finding the Value of Intangibles in Business. New Jersey: John Wiley \& Son.

Ibrahim, A. A., Elatrash, R. J., \& Farooq, M. O. (2014). Hoarding versus circulation of wealth from the perspective of maqasid al-Shari'ah. International Journal of Islamic and Middle Eastern Finance and Management, 7(1), 6-21. https:// doi. org/10.1108/IMEFM-06-2012-0053

Ibrahim, Wan Hakimah Wan., Ismail, Abd. Ghafar. \& Zabaria, Wan Najihah Wan Mohd. (2011). “Disclosure, Risk and Performance in Islamic Banking: A Panel Data Analysis". International Research Journal of Finance and Economy. Vol. 72.

IFSA. (2013). Islamic Financial Services Act 2013. Islamic Financial Services Act 2013.

IFSB-10. (2009). Guiding Principles on Shari'ah Governance Systems for Institutions Offering Islamic Financial Services. Islamic Financial Service Board (IFSB). https:/ / doi. org/10.1016/0198-0149(86)90009-9

Islamic Financial Services Board. (2005). IFSB1: Guiding Principles on Risk Management for Institutions (other than Insurance Institutions). Kuala Lumpur: IFSB.

Islamic Financial Services Board. (2013). IFSB15: Revised Capital Adequacy Standard for IIFS. Kuala Lumpur: IFSB.

Jarhi, Mabid Ali al- and Iqbal, Munawar (2001), Islamic Banking: FAQs, Jeddah: Islamic Research and Training Institute, Occasional Paper No. 4.

Khiyar, K. A. 2012. Islamic Banking and Economic Growth: A Review. The Journal of Applied Business Research, 28(5), pp. 943-956

Maruf Olayemi, A. (2017). The Challenges of Shari'ah Compliance In The Islamic Banking
Practices: Whether Ibn Al-Qayyim's Principles Of Muamalat Be. 14.

Mohd, Yusoff, H. 2004. Halal certification scheme, Standard \& Quality News 11, 4-5.

Mokhtar, S. A., Alias, R. A. and Abdul Rahman, A. (2006). Assessing Academic Computing in Malaysian Higher Education: A Value Chain Approach. Journal of Institutional Research South East Asia, 4 (12), 59-92.

Muda, Muhamad. \& Jalil, Abdullaah. (2007), "Islamic Financial Product Development: Shari'ah Analysis" Working Paper International Conference on Islamic Banking and Finance (IICiBF). The International Islamic University Malaysia.

Oz, e., Khokher, Z. u., Ali, M. M., \& Rosman, R. (2016). Shari'ah Non-Compliance Risk in the Banking Sector: Impact on Capital Adequacy Framework of Islamic Banks. IFSB Working Paper Series, 1-82.

Reyazat, F. (2012). Risk Management Framework in Islamic Banking: Basel II and Basel III, Challenges and Implications in Islamic Banking. Money and Economy, 6 (2), 69122.

Rosman, R., Che Azmi, A., \& Amin, S. (2017). Disclosure Of Shari'ah Non-Compliance Income By Islamic Banks In Malaysia And Bahrain. 14.

Rosman, R., Azmi, A. C., \& Amin, S. N. (2017). Disclosure of Shari'ah Non-Compliance Income by Islamic Banks in Malaysia and Bahrain. International Journal of Business and Society, 18, 45-58.

Salman, S. A (2018). Shari'ah Non-Compliance Risk Management In Takaful Industry. International Journal on Recent Trends in Business and Tourism. Vol 2 (2).

Sciences of Philadelphia (Vol. 13). West Sussex PO198SQ, England:John Wiley \& Sons Ltd, The Atrium, Southern Gate, Chichester,. https://doi.org/10.1155/1915/93252

Tjittes 2008, R.P.J.L. Tjittes, Islamitisch financieren in Nederland, Rechtsgeleerd Magazijn Themes, 2008-4, p.136-144

Yasin 2007, N. M. Yasin, Legal aspects of Islamic Banking: Malaysian Experience, Islamic Development Bank, 2007, p. 215-238 